\title{
Small And Medium Enterprises Training For Survival In A Competitive World
}

\author{
Ndiritu Caroline, MA \\ Ndiritu Anne, PhD \\ Kidombo Harriet, PhD \\ University Of Nairobi
}

doi: 10.19044/esj.2016.v12n19p181 URL:http://dx.doi.org/10.19044/esj.2016.v12n19p181

\begin{abstract}
This study explored the influence of Total Quality Management practices on performance of Small and Medium Enterprises. Youth Projects in Kajiado County, Kenya were used as the target population. One of the key TQM management practices is training of employees. The study sort to determine the influence of training of employees on performance on SMEs. The study was carried out on 168 youth group projects in Kajiado County.Questionnaires and interviews were used as research instruments. For triangulation purpose, the interview schedule was used to confirm the information captured by the questionnaire. Data was collected from both primary and secondary sources. The study used mixed method approach in the collection and analysis, to capture both the qualitative and quantitative data.Spearman's correlation was used to test the relationship between training and performance of SMEs. The analyses indicated a moderately positive relationship between training and performance of SMEs in Kajiado county which was statistically significant $r_{\mathrm{s}}=0.400, \quad p=0.600$. Based on the findings and conclusions of the study, it is recommended that to improve the performance of the youth groups, they should strive to ensure their product in the market is superior. This can only be ensured by equipping their employees with proper skills, knowledge and values through training.
\end{abstract}

Keywords: Training, Small and Medium Enterprises, Total Quality Management, Youth projects

\section{Introduction}

The importance of training to the success of any organization cannot be overemphasized. This is because of the fact that employees who have the required skills are able to perform better and increase efficiency and productivity of the organization. Such employees will also require less 
supervision thereby saving on the manager's time. Surveys indicate that trained employees are likely to have less accidents as they perform their duties at the work place. Since the overall performance of an organization is the sum total individual employee's performance, organizations should ensure that each individual is able to perform optimally both in quality and quantity.

Organizations are also known to be competing with each other worldwide. It is prudent therefore for an organization to be able to utilize their human resources more effectively. Organizations should strive to keep their human resources effectively to remain afloat. An organization that has trained employees also tend to have satisfied employees. This is because the employees are able to do their jobs with confidence and also get positive results from it. To compete favourably in the globe, organizations should also invest in their human resources (Pucik and Barsoux 2002).

Youth groups are formed by the coming together of the youth and purposing to create or establish a meaningful program that will pursue certain agendas. In Kenya a youth group is only recognized if it is registered under the Department of Social Services or the Registrar of Societies (Ouma,Osano \& Mullumba, 2002, Oduol et al., 2013). The youth have been defined in the 2010 constitution of Kenya as individuals between the ages of 18 and 35 years (Republic of Kenya, 2007). This group of individuals is considered as important in the development agenda of the country since it constituents the largest segment of the total population. It is imperative therefore that appropriate strategies policies and programmes be put in place because to the likely effect that this group can have in the economy.

Youth enterprises like all others are established with an aim of making profits. In Kenya the programmes are also aimed at assisting the youth to become self independence (Njuki et al. 2014). Other reasons that have been cited include reduction of youth's engagement in negative activities associated with idleness. The Kenyan government established a department of youth development with a sole aim of providing leadership, teamwork and allocated the youth funds to develop their projects (National youth policy, 2007). The youth enterprise development Fund (YEDF) was established in 2006 to assist the youth in this agenda.

Although the government has put in a lot of money in youth projects, little has been witnessed from the performance of these projects. Some projects that have been operating have since ceased to do so while others are operating less that optimally (Njuki et al.2013). This study sought to establish the reasons behind this poor performance. The study was carried out to investigate the role played by TQM practices in the performance of youth projects. Training as a major TQM practice was studied. Specifically this study sort to 
1. Establish the status of employees' training in the youth projects

2. Determine the influence of employees' training on the performance of youth projects

\section{Statement of the problem}

A lot of money has gone into the establishment of youth programmes. Youth projects that do not succeed is an indication that the Kenya youth empowerment project (KYEP) is not achieving its goal. KYEP is a program initiated in 2010 with credit from the World Bank to support the government of Kenya to improve on the youth employability. There have been deliberate efforts to engage the youth in development. This is because youth development projects are a huge contributor towards the country's GDP (Mburu \& Makori 2015). The divisional youth enterprise development fund committee (divisional YEDFC) was formed purposely to identify and assist functional youth groups in the region to access loans.

Unfortunately studies report that many youth projects do not succeed. For instance Njuki et al.(2014) report that despite the government's effort to promote the youth projects not much has been witnessed. Their study reveal that most youth projects have ceased to operate while others are underperforming. Attempts have been made to identify the causes of failure of youth projects. For instance, .Amenya et al (2011) show that the causes of failure of youth projects are lack of funding, management skills, lack of stakeholder support. Mburu \& Makori (2006) support this by reporting that many fail because of managerial issues. The managerial issue comes out as a clear indication of the cause of inability to implement the youth projects.

Bowen, Morara and Muriithi (2009) also have observed that over $50 \%$ of youth projects fail within the first three years. For instance the youth enterprise and development fund launched in 2006; has been on the decline as 57 million is reported to have been lost through misappropriation and mismanagement of funds, political interference and leadership wrangles. "Kazi Kwa vijana (2009) World Bank funded project collapsed in 2011 due to mismanagement and misappropriation of funds. According to youth initiative Kenya 2004 report, the main problem with the association and projects is that they are run by inexperienced youth who do not know how to handle youth affairs. Also they are threatened and harassed by police and they lack the goodwill of the surrounding society. The enrolment can be attributing to unemployment, poverty and the rapid growth that is unplanned.

\section{Literature review}

Youth projects are diverse in activity and organization. However the approach of TQM practices cuts across in all the youth group projects that are undertaken across the country. Mburu (2015) describes the youth as 
persons that fall between the ages of 18-35. Youth groups are formed by the coming together of the youth and purposing to create or establish a meaningful program that will pursue certain agendas. In Kenya a youth group is only recognized if it is registered under the Department of Social Services or the Registrar of Societies (Ouma, Osano \& Mullumba, 2002, Oduol et al., 2013). Mburu (2015) suggests that platforms have been created to assist the youth groups and the difference should be appreciated as a heterogeneous group. There are those that have members that are illiterate, needy and unstable of which they would acquire skills to be able to manage the youth group projects.

There are several approaches of TQM practices. Different scholars have defined the practices based on the situations and type of organizations and industry. They were looked at from manufacturing organizations, service industry, government, healthcare, and banking and education sector. Review of different TQM practices by different scholars seems to concur on the following major practices: top management commitment, process management, and training of employees, quality of product design and quality information. This study examined the influence of employee training on performance in youth group projects.

\section{Training of employees and performance of SMEs}

Quality training is when the executed processes by the team are continuously improving. A team is well structured and training that is intentional is carried out and performance assessed against the intended objectives. Gharakhayi et. al. (2013) claims that fear of employees hinder the achievement of performance. Hence intense education, training and retraining go a great length in achieving continuous improvement of quality and also give employees some job security. Stone (2002) reports that the main role of training is incorporating and achieving organizational goals through the workforce. Fakhar and Anwan (2008) also observed a positive relationship between job experience and performance as job experience results in increase in both skills and competence. Iftikhar and Siraj-ud (2009) also observed that employee performance in health sectors increased because of increase of training and development.

Robert and Frank (1998) in their research found that training not only develops but improved managerial skills as it led to efficiency and cost control. Raja et.al. (2011) state that human resource is the backbone of any organization. This is why huge amounts of money are invested on the human resource capital as it majorly improves the performance. Ginsberg (1997) says that a good training is that which is designed to meet both the needs of the employees and organization. 
Scholars have seen that training has a crucial role in performance, For instance Tsaur and Lin (2004) assert that bad training doesn't result into anything other than loss of both time and money. Training and development result in increased performance (Shepard et.al 2003). In Raja (2011) proved the hypothesis that the training design has a significant effect on the performance. Training has many dimensions and as Deming (1982) reports, on-job training is better as one grasps more and it saves time and costs (Fynn et.al 1995). Thomas (1997) also concludes that it is nearly impossible for an employee to perform well if he/she has not pre-training. Karanja (2014) also confirms this through a study carried out a study in Nyeri Kenya. The performance of the enterprises was measured by their growth rate over time. Descriptive survey design was used in the study and data was collected from a population of 812. Pearson Moment Correlation Coefficient was used in the analysis. The findings indicated a positive relationship between training and performance of youth projects.

Farsijani (2007) says that productivity in an organization is improved if a stimulation attitude is based on continual improvement activities. It would also be effective if service performances were in the same direction with trading duties and culture development based on the flexibility of staff and when education and multi skilling were utilized. Effective training and learning capabilities ensure consistency in the production process. Unique behavior is a distinguishing factor within the industry. If employees are trained then it is possible to have high quality products and services. Training also increases productivity of employees within an organization (Sadikoglu \& olcay 2014)

Sadikoglu \& olcay (2014) continue to say that training of employees allows them to understand the structure of the firm and industry at large. Trained employees develop some sense of loyalty to the firm. Their ability to perform a task at. Perform excellently makes them confident, builds their morale and the firm is assured of high quality products being produced.

\section{Research methodology}

To establish the influence of training on performance of youth group projects, 168 youth groups from Kajiado North sub-county were interviewed. These groups were drawn from all the youth groups that benefited from youth centre funding, training and facility. This however was a small population of the thousands of youth that have been registered in Kajiado social service and welfare office in 2015. The mixed methods approach consisting of both quantitative and qualitative methods, was used. Questionnaires and interviews were used as research instruments. For triangulation purpose, the interview schedule was used to confirm the information captured by the questionnaire. This approach was especially 
important for triangulation purposes.The independent variable was training as one of TQM practices and the dependent variable was performance. The data was analysed using Spearman's correlation which was used to test whether there was any significant relationship between the variables.

\section{Results}

The study was guided by the following hypothesis:

\section{$\mathrm{H}_{0} 1$ : There is no significant relationship between training of employees and performance of SMEs}

The respondents were asked whether they undergo training to be able to use the new machinery and equipment that are introduced in the organization. The Statistical Package for Social Science (SPSS) software was used to establish possible relationships between training of employees and performance of SMEs. The findings are in Table 1

Table 1: Mean and standard deviations of SMEs based on their training

\begin{tabular}{crcc}
\hline & Mean & Std. Deviation & $\mathrm{N}$ \\
\hline $\begin{array}{c}\text { Training of } \\
\text { employees }\end{array}$ & 119.9600 & 52.55819 & 5 \\
$\begin{array}{c}\text { Performance of } \\
\text { SMEs }\end{array}$ & 125.5000 & 125.94311 & 4 \\
\hline
\end{tabular}

The mean of training of employees was 119.96 and the mean for performance was 125.5. To determine whether there was a correlation between training of employees and performance of SMEs, a Spearman's rank order correlation was run to determine the relationship between training of employees and performance of SMEs. The results are indicated in Table 2.

Table 2: Spearman's correlation analysis of SMEs based on training of employees

\begin{tabular}{ccccc}
\hline & & $\begin{array}{c}\text { Training of } \\
\text { Employees }\end{array}$ & $\begin{array}{c}\text { Performance of } \\
\text { SMEs }\end{array}$ \\
\hline $\begin{array}{c}\text { Spearman's } \\
\text { rho }\end{array}$ & $\begin{array}{c}\text { Training of } \\
\text { employees }\end{array}$ & $\begin{array}{c}\text { Correlation } \\
\text { Coefficient } \\
\text { Sig. (2-tailed) } \\
\text { N }\end{array}$ & 1.000 & .400 \\
& $\begin{array}{c}\text { Performance } \\
\text { of SMEs }\end{array}$ & $\begin{array}{c}\text { Correlation } \\
\text { Coefficient }\end{array}$ & 5 & .600 \\
& Sig. (2-tailed) & .400 & 4 \\
& & N & .600 & 1.000 \\
& & 4 &. \\
\hline
\end{tabular}

Table2 indicates a moderate correlation between training of employees and performance of SMEs, which was statistically significant $r_{\mathrm{s}}=0.400, p=0.600$. Therefore the null hypothesis was rejected and the alternative hypothesis accepted. There is indeed a significant relationship between training of employees and performance of SMEs. Majority of the leaders of these youth enterprises also reported they had no relevant skills. 


\section{Conclusion}

The study reported a positive correlation between training and performance of youth enterprises. Based on this findings, the study concludes that entrepreneurial training is critical to the success of any business. There is no need to engage in any entrepreneurial venture unless one has the necessary skills.

\section{Recommendations of the study}

Based on the findings and conclusions of the study, it is recommended that to improve the performance of the youth groups, the government should provide prior training before providing the youth with finances for entrepreneurship ventures. This training ensure their products in the market are superior and are therefore able to compete well in the market. Youth leaders should engage the members that are also trained. Necessary skills should also be included in the school curriculum especially at the primary school levels to ensure that even the school drop-outs have the basics in entrepreneurship skills.

\section{References:}

Amenya, C.O., Onsongo, S Huka, G \&Onwong’a, M (2011). An analysis of the challenges facing youth enterprise Development fund: A case study of Nyaribari Chache Constituency, Kenya. AIBUMA publication

Bowen, M., Morara, M., \& Mureithi, S. (2009). Management of business challenges among small and micro enterprises in Nairobi-Kenya. KCA journal of Business Management, 2(1), 16-31.

Deming, W. (1986). Out of crises. Cambridge: Addison-Wesley.eming, W.E 1982. Quality,

Productivity and Competitive Position, MIT Center for Advanced Engineering, Cambridge, MA.

Ede, F. O., Panigrahi, B., \& Calcich, S. E. (1998). African American students' attitudes toward entrepreneurship education. Journal of Education for Business, 73(5), 291-296.

Evans, P. Pucik, V., \& Barsoux, J.L (2002). The global challenge: Framework for International Human Resource Management.

Fakhar U. F, Anwan K (2008). Case of Pearl continental hotels in Pakistan, relationship training with employees performance in Hoteling Industry.

Farsijani H (2007). World class of organizations and total quality management. Industrial research and Training centre of Iran

Flyyn, B.B., Schroder, R.G., Sakakibara, S. (1994). A Framework for Quality Management Research and an Associated Measurement Instrument. Journal of Operations Management, 11,339-366. 
Gharakhani, D., Rahmati, H., Farrokhi, M. R., \& Farahmandian, A. (2013). Total quality management and organizational performance. American Journal of Industrial Engineering, 1(3), 46-50.

Ginsberg (1997). To some employers an expanded family leave act wont fly. Washington Post

March. Iftikhar Ahmad and Siraj ud Din,Gomal(2009) Medical College and Gomal University.

Karanja, B. N. (2014). Influence of entrepreneurial training on performance of youth enterprises: a case of stryde project in Nyeri county, Kenya.

Kourilsky, M. L., \& Walstad, W. B. (1998). Entrepreneurship and female youth: Knowledge, attitudes, gender differences, and educational practices. Journal of business venturing, 13(1), 77-88.

Mburu, M., \& Makori (2015). Management challenges facing implementation of youth enterprise funded projects in Nairobi County. Journal of business change and management 2(34),636-661

Mburu, M. (2015). Management challenges facing the implementation of youth development projects in Kenya. A case study of youth enterprise funded projects in Nairobi County. Strategic Journal of Business \& Change Management, 2(1).

Njuki, H. M., Mwangómbe, C. W., Okoth, O. N., \& Mutua, M. W. (2013). An investigation into the factors that affect performance of youth group income generating projects in Kenya: A case of Taita District. European Journal of Business and Management, 5(17), 2222-2839.

Oduol, S., Okelo, S., Ada, F., Awiti, A.,Onyango, M., Ogutu, M \& Odera, O (2013). Effect of the Youth Enterprise Development Fund on Youth enterprise In Kenya. international Journal of Advances in management and Economics, 2(1)

Ouma, R., Osano, P., \& Mullumba, F. (2002). The Status of Youth and children in Kenya: A Review of the Implementation of Agenda 21 in Kenya. In Kenya NGO Earth Summit 2002 Forum, Nairobi.

Parasuraman, A (2010). Service productivity. Quality and innovation. International journal of quality in service Sciences.

Raja, A., Ghafoor, K Furan A., \& Muhammad A. (2011). Impact of training and development on performance.

Republic of Kenya, (2007) Ministry of State for Youth Affairs - Strategic plan 2007-2012 Nairobi: Office of the Vice President and Ministry of State for Youth Affairs.

Sadikoglu, E., \& Olcay, H. (2014). The effects of total quality management practices on performance and the reasons of and the barriers to TQM practices in Turkey. Advances in Decision Sciences, 2014.

Stone R J. (2002), Human Resource Management 2nd Edition, Jhon Wiley \& Sons 2002. 
Thomas N. Garavan. (1997). “Interpersonal skills training for quality service interactions” Industrial and Commercial Training Vol. 29 (3) ,pp:70-77 Tsaur, S. H., \& Lin, Y. C. (2004). Promoting service quality in tourist hotels: the role of HRM practices and service behavior. Tourism Management, 25(4), 471-481.

Wiklund, J., \& Shepherd, D. (2003). Knowledge-based resources, entrepreneurial orientation, and the performance of small and medium-sized businesses. Strategic management journal, 24(13), 1307-1314. 